\title{
AN EVALUATION OF ORGANISATIONAL GROUNDWORK AND LEARNING OBJECTIVES FOR NEW PRODUCT DEVELOPMENT
}

\author{
Jonathan D Owens \\ Lincoln Business School \\ University of Lincoln \\ UK
}

\begin{abstract}
This paper discusses New Product Development (NPD) Process and the perception required for effective NPD Learning (NPDL). A model of learning for NPD organisations is presented and the necessity to assess progression towards learning objectives at the individual, job and organisation level is shown. Three aspects of organisational groundwork are identified and discussed. These include developing the NPD process, implementing the NPD strategy and allocating resources for NPD and NPDL. Ten sets of learning objectives are identified and discussed. These are organisational analysis, barrier demolition, team working, flexible problem solving, use of advanced support tools, facilitating communication, maintaining communication, decision making, assessment of the NPD process and NPDL, and NPD risk analysis. It is proposed that adopting both an organisational needs analysis and individual needs analyses can support the development of NPD organisations. These analyses will identify the groundwork that should be undertaken by the organisation and the initial learning objectives for the individuals. The progression of NPD through the NPD process can then be assessed and implemented sufficiently.
\end{abstract}

\section{INTRODUCTION}

The long-term survival of a business often hinges upon its ability to successfully introduce new products into the market place. These new products and their successful development can be the lifeblood of a company. Thus, NPD is a major consideration for most organisations. New products can provide the stimulus for the company to grow and produce profitable returns. Additionally, new products can gain new markets and market shares and subsequently help to defend against competitive pressures. Subsequently, it is of little surprise that across industry NPD is one of the leading areas for focus, as companies seek to reduce time to market, access new technologies and develop more and better products. Therefore, the 
regular development of new products can potentially provide satisfaction to customers, meet continually changing needs and market requirements. The implementation of new products is necessarily dependent on the skills and competencies of the individuals within organisations in promoting the key success drivers for NPD or being able to learn such skills and competencies. Three questions are posed that are closely entwined with successful NPD:

1. What skills or competencies are required for NPD?

2. Can a learning framework be used to promote such skills?

3. Is the organisation ready for NPD?

More and more organisations are looking into how to drive their new product from concept to consumer, both quickly and with fewer mistakes. This will prove critical to success, especially in the latter stages of NPD. There is no one easy answer on how to do this and, in order to get started; it is therefore necessary to establish what is required. This paper presents the importance of having:

- A framework for NPD learning and change

- Undertaken adequate preparatory organisational groundwork for NPD

- Identifying the skills and competencies required to promote NPD

Together these can then form a reference grid that can aid in the quest for new product success. The significance of assessment throughout NPD and NPD learning (NPDL) is outlined and the processes are explained. Careful consideration must be taken of the individual, the team, the process as well as the product development and assessment (Figure 1) and it is clear that the quest for new product development cannot be taken by an isolated team.

Figure 1. A Continuous Development Model for NPDL Environment. 


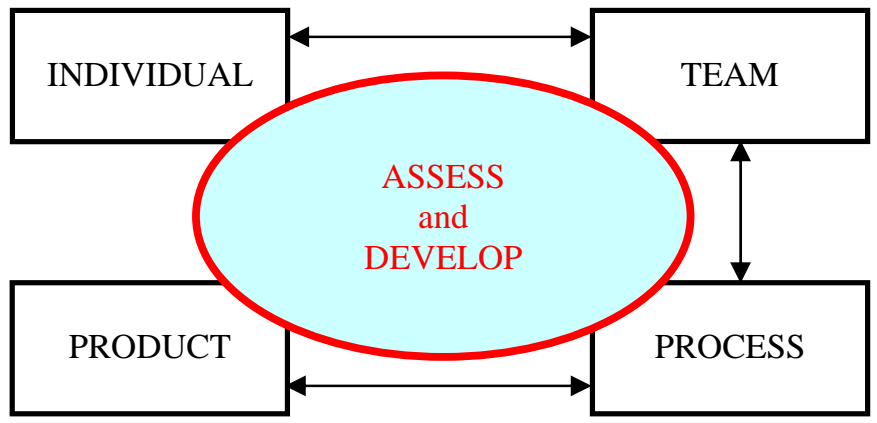

\section{DEFINING A NEW PRODUCT}

A new product can be classified as one not previously manufactured by a company [9, 12, 19, 31, 40]. One of the foremost aims of any development programme should be to get the right product to the market and/or customer as quickly as possible. If implemented effectively this can limit the chance of a competitor gaining an advantage by first entry, and therefore enjoying the potential benefits of an early market position. The cost of development, whether large or small, is a burden on the cash flow of an organisation and quite often pressure will be applied for an early payback of capital outlay [44]. For example, marketing functions can expend vast resources determining which products should be offered to particular markets and at what prices. Thus, restrictions on new product scope that are imposed are usually derived from a combination of the mission statement of a company and the attractiveness of the market [13].

\section{A FRAMEWORK FOR LEARNING AND CHANGE}

A framework for learning (figure 2, developed from Heywood, 1977) includes elements of course objectives, teaching strategies, assessment and evaluation. Learning objectives labelled learning and training needs in businesses) are agreed at the first stage of the education process. Hence any NPDL project should start with an analysis of learning. Individuals' training needs, as they are called by employers, can be determined by a training needs analysis (TNA) process: measuring the gap between the 
employees' skills and the skills required for the job of NPD. Employees may have been identified as potential members for the NPD team through previous TNA processes.

Figure 2. A Framework for Learning.

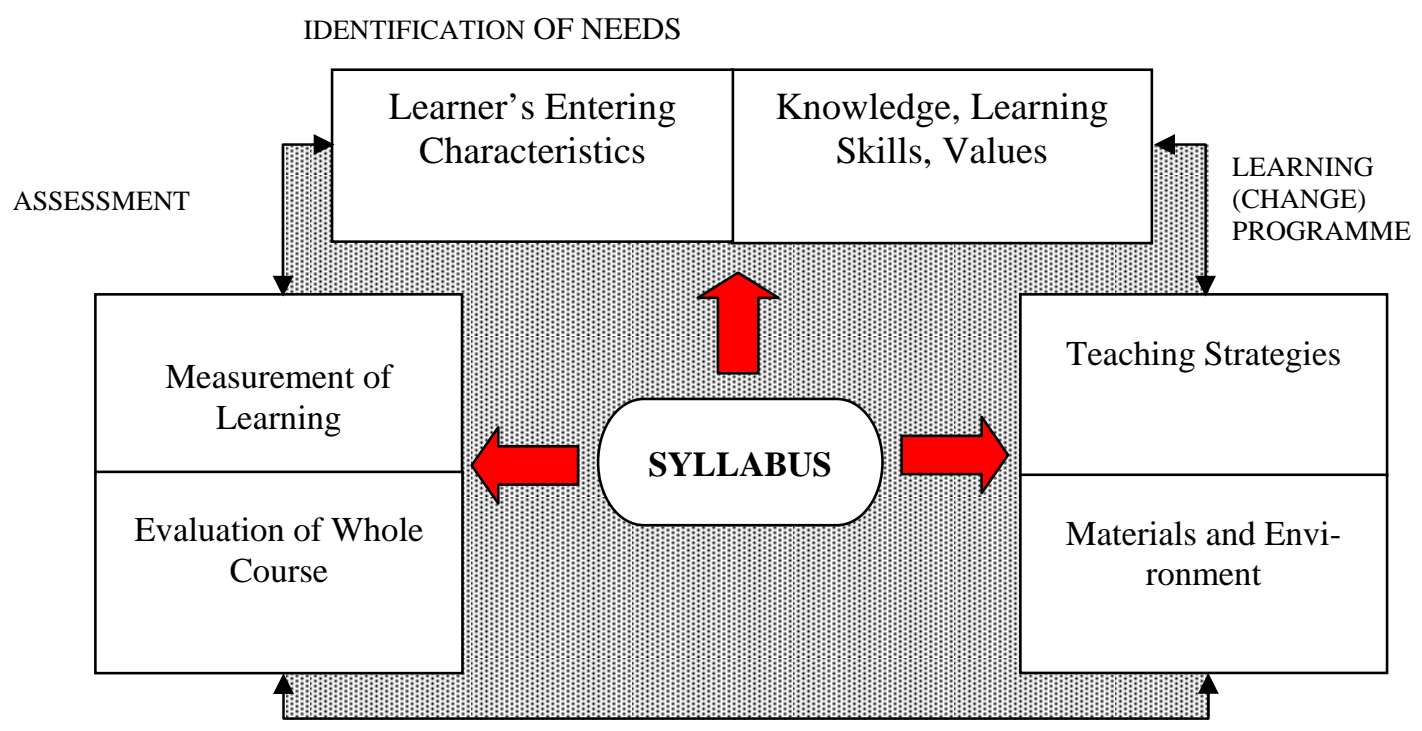

It may be necessary for individuals to engage in a comprehensive series of psychometric assessments, firstly in order to consider their suitability to fit into the NPD team and secondly to determine their entry characteristics for learning. The needs of the NPD employer can be used to determine a list of skills and competencies, or learning objectives, required by individuals in the NPD team. This list could be used to prescribe any course requirements. More importantly the learning framework can be applied to the individual, the team and the organisation. This gives rise to a three by three check-table (Table 1), which is necessary, as the organisation and team need to learn as well as the individual. 
An Evaluation of Organisational Groundwork and Learning Objectives ...

Table 1. A Learning and Change Framework Check-table.

\begin{tabular}{|c|l|l|l|}
\hline & \multicolumn{1}{|c|}{$\begin{array}{c}\text { NEEDS } \\
\text { IDENTIFICATION }\end{array}$} & $\begin{array}{c}\text { CHANGE } \\
\text { PROGRAMME }\end{array}$ & \multicolumn{1}{|c|}{ ASSESSMENT } \\
\hline ORGANISATION & $\begin{array}{l}\text { Organisational } \\
\text { Analysis }\end{array}$ & $\begin{array}{l}\text { Organisational } \\
\text { Groundwork }\end{array}$ & $\begin{array}{l}\text { 1. Organisational Audit } \\
\text { 2. Individual Examination } \\
\text { 3. Job Performance } \\
\text { 4. Team Performance } \\
\text { 5. Organisational Results }\end{array}$ \\
\hline TEAM & $\begin{array}{l}\text { Personal } \\
\text { Profiling }\end{array}$ & $\begin{array}{l}\text { Team } \\
\text { Building }\end{array}$ & \\
\hline INDIVIDUALS & $\begin{array}{l}\text { Training Needs } \\
\text { Analysis }\end{array}$ & $\begin{array}{l}\text { Training } \\
\text { Courses }\end{array}$ & \\
\hline
\end{tabular}

\section{LEARNING AND CHANGE ASSESSMENT}

Arthur [1] standardised the terminology of "assessment", "evaluation" and "validation" with respect to training courses (Table 2) and "course” may be synonymous with "change" in the organisational case.

Table 2. Assessment Terminology.

\begin{tabular}{|l|l|}
\hline TERM & MEANING \\
\hline Evaluation & $\begin{array}{l}\text { Is the course cost justified? } \\
\text { Is this course better than any alternative? }\end{array}$ \\
\hline $\begin{array}{l}\text { Internal } \\
\text { validation }\end{array}$ & How well is the course doing what it sets out to do? \\
\hline $\begin{array}{l}\text { External } \\
\text { validation }\end{array}$ & Do course objectives meet job requirements? \\
\hline $\begin{array}{l}\text { Individual } \\
\text { assessment }\end{array}$ & How well have individuals done in reaching course objectives? \\
\hline
\end{tabular}

Any comprehensive educational or change process incorporates an evaluation of the whole process plus an appraisal of the progress of individuals towards achieving the learning or change objectives. In NPDL the general course objectives will be to promote the skills required for NPD. Then there will be specific objectives for individuals determined by the TNA process. As the NPD process progresses, new learning objectives 
may have to be set, after feedback, forming a continuous learning system. Complications arise with the traditional educational assessment system when used in businesses. Alignment of the organisation's strategic objectives with the individual's objectives and assessment has to be made at a series of levels and along a range of domains. The main strategic objectives in consideration here are NPD and NPDL. Kirkpatrick [22] suggests four levels of evaluation including training; reactions, learning, behaviour and results (Figure 3), these levels can be applied to the individual, team and organisational change.

Figure 3. Kirkpatrick’s Evaluation Hierarchy.

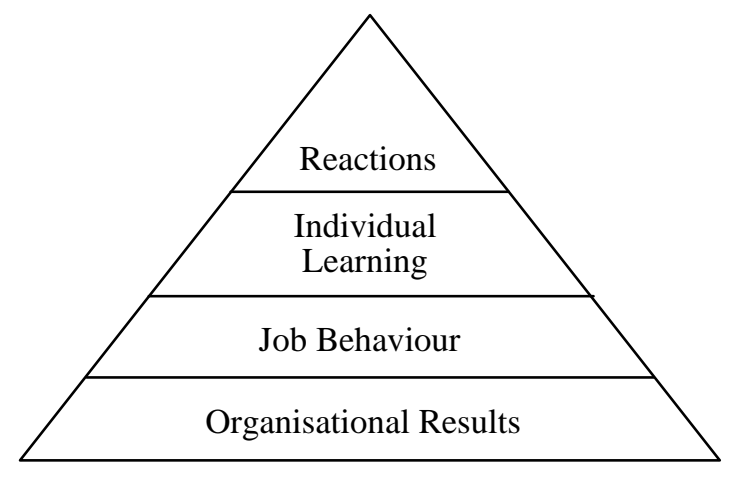

For individuals, most training courses are assessed at the reaction level. At this level an assessment of the contentment felt by the learners is made directly after learning. Apparently "hard" evidence about course quality is made at this level where Likert type rating scales are used to collect "quantitative data", however such scales are often constructed subjectively. Mann and Robertson [30] point out that scoring highly at the reactions level does not necessarily mean that learning or improvement in job performance will take place. The learner or another person can take more reliable and valid measures at the behaviour and results levels. Assessment of individual learning is made at the second level. Here the gain of skills in the cognitive domain and practical skills in the psychomotor domain are measured [4]. Nearer to the reaction level changes in attitudes are measured. At the third level an assessment of change in job behaviour is made. Here improvement in job performance is measured. Ostroff [33] suggests that supervisor or self, behaviour and skill, rating scales could be used to indicate the improvement in the job. However, the reliability of 
An Evaluation of Organisational Groundwork and Learning Objectives ...

such scales is uncertain and more research is required, as there have been few investigations in actual organisational settings. Fourth level assessment investigates the results of the learning programme in the organisation. If the organisation has adopted a total quality management philosophy they may well be using frameworks like the Business Excellence Model (European Foundation for Quality Management: EFQM model) and these processes can measure organisational results [5]. Assessments at all four levels are required for NPDL and can aligned with to the information gathering phases of a NPD stage gate process (see Figure 8) at which point learning objectives for subsequent stages of the NPD process can be clarified.

\section{A MODEL OF LEARNING FOR NPD ORGANISATIONS}

Attempting to create a new product with a pool of talent that is inadequately prepared, or lacks the skills needed to apply the knowledge they possess effectively, is an exercise in futility [12], so a model of learning for NPD organisations is required to inhibit this futility. The learning framework presented in figure 2 can be simplified into a cycle (Figure 4) based on Shewhart's Plan-Do-Check-Act cycle popularised by Deming [15]. First the learning needs of the individuals are identified then the learning objectives are set. The learning programme is undertaken followed by an evaluation. This cycle is not sufficient for business organisations as it only applies to individual learning. Similar cycles can be proposed for the team, the organisational process and even the product.

In order to evaluate effective learning in the NPD organisation this cycle can be combined with Kirkpatrick's [22] evaluation hierarchy producing a model for learning in NPD organisations (Figure 5). This has been developed from a similar model proposed by Arthur [1]. In the case of the NPD organisation, the strategic objectives of the organisation will be aligned with individual learning needs because the individuals will have been selected to join the NPD team. 
Figure 4. The Simplified Learning Framework for NPDL.

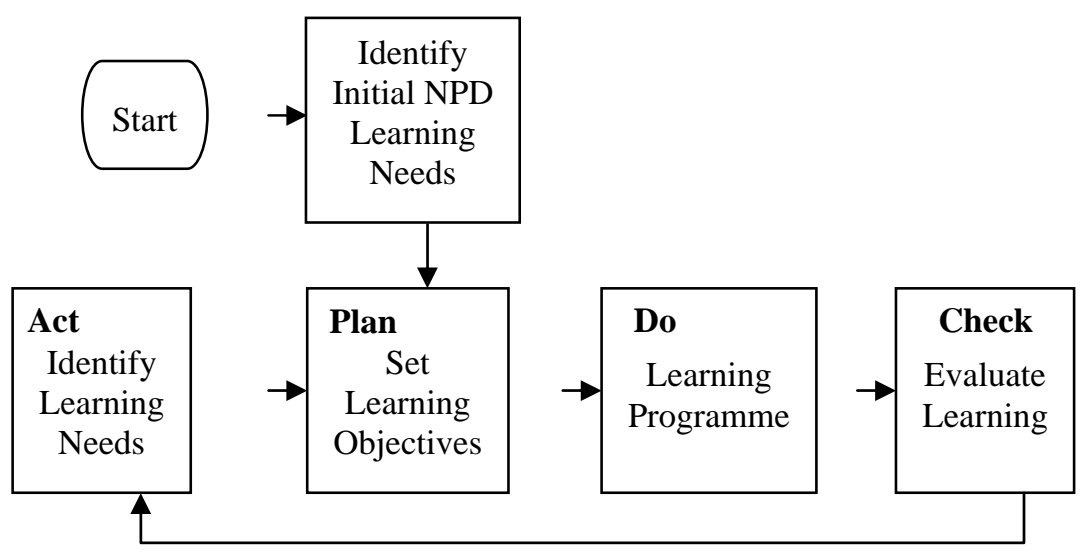

The learning objectives will be set at each level after the needs identification process. The assessment at each level feeds into a review of needs at the corresponding level, the assessment process at higher levels and the overall course evaluation.

Figure 5. A Model of Learning for NPD Organisations.

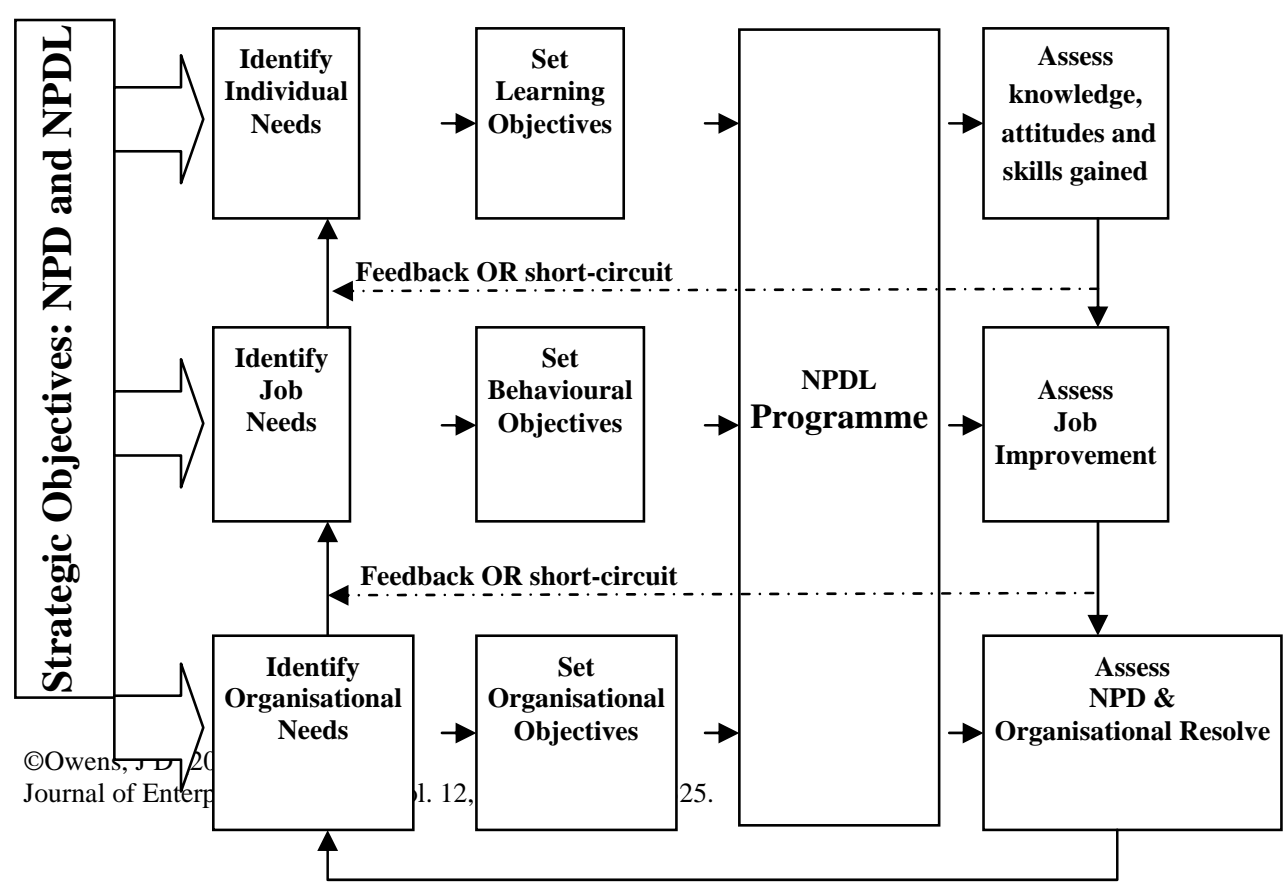


An Evaluation of Organisational Groundwork and Learning Objectives ...

\section{ORGANISATIONAL NEEDS ANALYSIS}

It is understood that new product success, or indeed the NPD process, cannot be measured in absolute terms. It should be defined and interpreted according to realistic goals and objectives that reflect the specific new product situation. The study of new product success (and failure) has been a preoccupation of academic researchers for several years. Various studies $[12,16,18,31]$ have used different measures to report back from a wide range of industrial and market sectors. Subsequently drawing valid comparisons and conclusions is difficult. Although it is difficult to decide on common factors that lead to new product success, it is possible to draw two fundamental points from the various studies undertaken:

1. New product success is highly situational

2. No one factor can be clearly defined for new product success.

NPD success is highly situational and there are few isolated actions that can be taken in order to assure NPD success. Therefore, organisations that develop new products must carefully analyse their own situation, and recognise the multiple factors that may determine success. This forms the first set of individual learning objectives and concerns organisational analysis.

Returning to the organisational needs analysis (Table 1) there is a requirement for the organisation to know just what the cornerstones of success for NPD organisations are, then it can audit itself against those. The research literature questions what discriminates between success and failure and the reasoning behind the factors. In some cases this questioning is vital, in order to grasp a better understanding of the development of new products [40]. Research by Cooper and Kleinschmidt [7], illustrated in figure 6, indicates the three cornerstones of NPD success, Process, Strategy and Resources. The three critical success factors were found to be the drivers of new product performance at the organisation unit level. These form three pieces of groundwork that an organisation needs to align with for NPD. 
Jonathan Owens

Figure 6. The New Product Performance Triangle and the three Cornerstones of Performance [7].

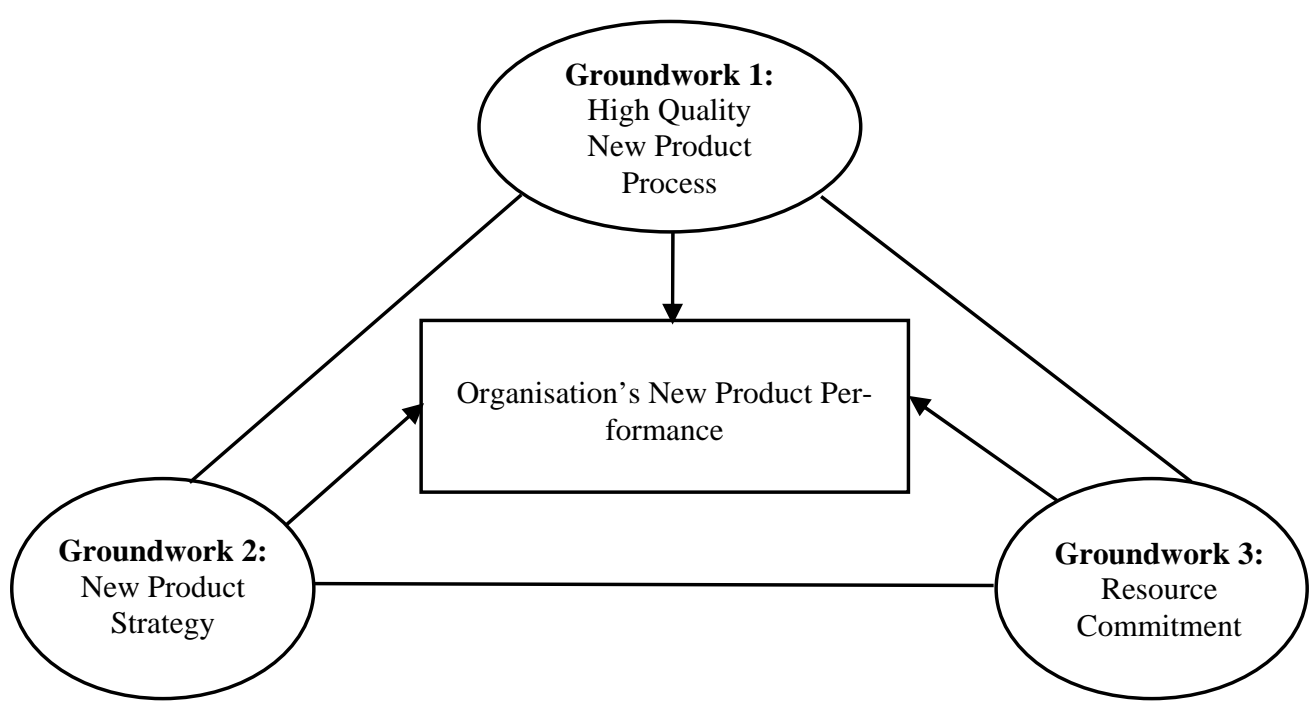

Ten different performance measures were considered by Cooper and Kleinschmidt [7] and these can be summarised as having a product innovation strategy for the business that ties product development to the company strategy, that identifies areas of focus for product development, that has a longer term drive, and finally that is clearly enunciated to all in the company, is likely to lead the company towards success. Adequate spending and resources is another factor that can contribute to company NPD success, by having the necessary people and training, research and development funding in place. Then having a high quality new product process to guide product innovations from idea to launch is most important. This is least appreciated, but can have the biggest impact on the company's NPD performance. Although, there are no hard and fast rules to defining the contents of a critical list of factors that might aid NPD success, an integration and balance of best practices and tools that are essential ingredients of the process is essential [13]. 
An Evaluation of Organisational Groundwork and Learning Objectives ...

\section{Groundwork 1: Developing the NPD Process}

A sequential NPD process is shown in figure 7, which is the most basic and traditional approach to NPD. In this process, once each stage has been completed the information gained is passed onto the next function in the process. However, the fundamental problem with the traditional approach to NPD is that the information flows sequentially from department to department, and forms a problematic 'over the wall' style development, as demonstrated in Figure 8.

Figure 7. Sequential NPD Process [41, 37].

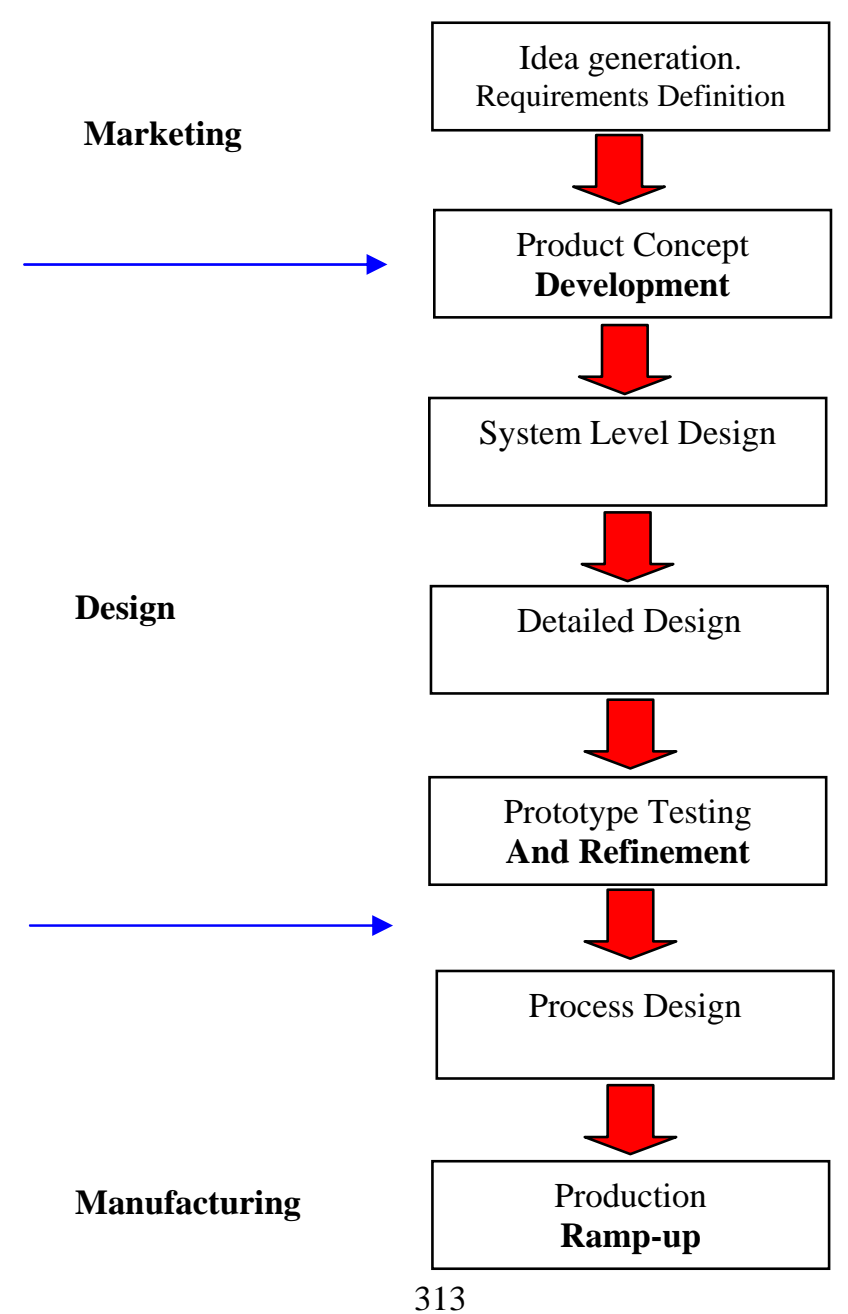

(c) Owens, J D (2004)

Journal of Enterprising Culture, Vol. 12, Issue. 4, pp 303-325. 
This both increases the time from product concept to product launch and increases the number of formally documented engineering changes late in the process. Both these problems delay the time to break-even and the start of making profit. Also implicit in the term 'over the wall' engineering is a complete lack of team working and understanding of other departments' problems, which can result in late, over-expensive and poor quality products. So the first piece of groundwork concerns the facilitation of the NPD process and the removal of barriers that impede the flow of information.

Figure 8. Typical ‘Over-the-Wall’ Engineering Approach.

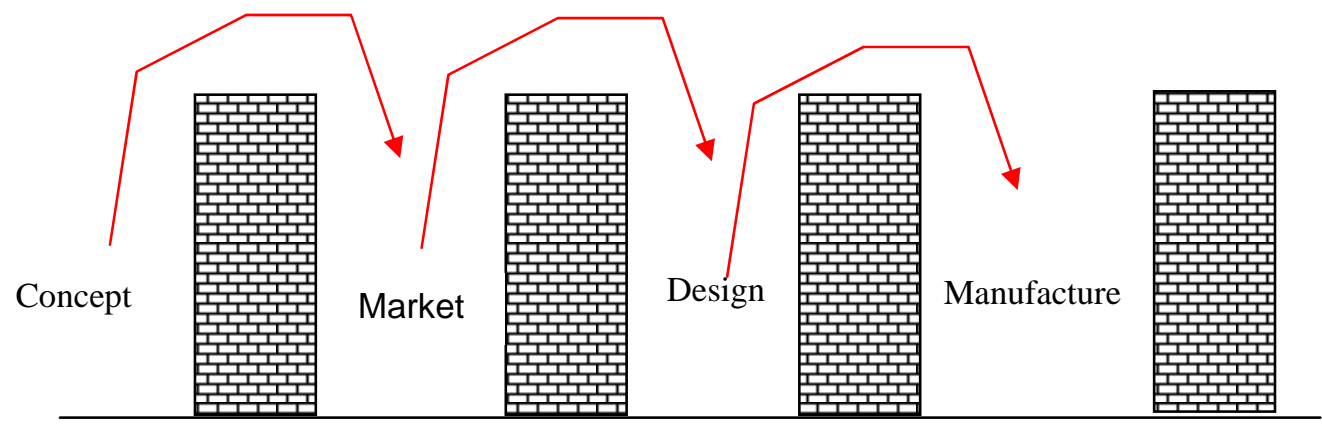

The effect of these late changes to the product is compounded, as it takes longer to evaluate each change the further down the development process it is [12]. Consequently, it is often too late to action a large proportion of the proposed changes due to the excessive costs of these late changes. Quite often, and where appropriate, these changes are designed out on a next generation new model [13]. Table 3 demonstrates how the cost of change increases as the design progresses. The example used is the electronics industry, but the increase of cost is likely to follow a similar pattern for other highly technical industries.

Table 3. The Increasing Cost of Design Changes in the Electronics Industry [32].

\begin{tabular}{|l|l|}
\hline STAGE & RELATIVE COST (£) \\
\hline
\end{tabular}


An Evaluation of Organisational Groundwork and Learning Objectives ...

\begin{tabular}{|c|c|}
\hline Concept. & 1 \\
Detail design. & 10 \\
Tooling. & 100 \\
Testing. & 1000 \\
Post-release. & 10000 \\
\hline
\end{tabular}

The predictable result of a sequential NPD process with a large number of late changes is that the development budget is exceeded and the product cost is too expensive to make an acceptable profit [9]. As a result, most cost reductions are often too late to be cost effective. They are implemented at a late stage where most of the product's budgets have already been consumed. Such knowledge about the relative costs at different stages is invaluable and will provide some knowledge for risk assessment, and information for the choice of course modules and assessment of NPD.

\section{THE STRUCTURED NPD PROCESS}

With shorter life cycles and the demand for greater product variety, continual pressure is put on NPD teams to produce a wider and varying portfolio of new product opportunities and to manage the risks associated with progressing these through from initial development to eventual launch. In simple terms the risk of failure must be minimised. In order to deal with this both effectively and efficiently, attention has been focussed on systematic screening, monitoring and progression frameworks such as Cooper's stage gate approach $[8,10]$. Most of these ideas are not in themselves new; for example, Lawrence and Lorsch [24] drew attention to cross-functional team working and co-ordination mechanisms back in the 1960s, and Cooper [10] has reported on NASA's 'phased review process' as a stage gate model also dating back to the same period. It can be argued that there is now a growing consensus about integrating the varying tools and techniques available in the 'new model of good practice'. Table 4 lists some of the key features of the emergent model. This includes the individuals' need for flexible problem solving and the use of advanced support tools (objectives sets 4 and 5 , Table 3 ). 
Table 4. Groundwork from the NPD 'New Model of Good Practice' *. (*Table based 10, 14, 21, 26, 28, 29, 35, 38, 39, 43.)

\begin{tabular}{|c|c|c|}
\hline TARGET & SUBJECT & CHARACTERISTICS \\
\hline \multirow{5}{*}{ PROCESS } & $\begin{array}{l}\text { Systematic process } \\
\text { for progressing new } \\
\text { products. }\end{array}$ & $\begin{array}{l}\text { Stage-Gate Model. } \\
\text { Close monitoring and evaluation at each stage. }\end{array}$ \\
\hline & $\begin{array}{l}\text { Early involvement of } \\
\text { all relevant } \\
\text { functions. }\end{array}$ & $\begin{array}{l}\text { Bring key perspectives into the process early enough to } \\
\text { influence design and prepare for downstream problems. } \\
\text { Early detection of problems leads to less rework. }\end{array}$ \\
\hline & $\begin{array}{l}\text { Overlapping/Parallel } \\
\text { Working. }\end{array}$ & $\begin{array}{l}\text { Concurrent or simultaneous engineering to aid faster } \\
\text { development whilst retaining cross-functional in- } \\
\text { volvement. }\end{array}$ \\
\hline & $\begin{array}{l}\text { Appropriate project } \\
\text { management } \\
\text { structures. }\end{array}$ & $\begin{array}{l}\text { Choice of structure (matrix/line/project/heavyweight } \\
\text { project management) to suit conditions and task. }\end{array}$ \\
\hline & $\begin{array}{l}\text { Learning and } \\
\text { Continuous } \\
\text { Improvement. }\end{array}$ & $\begin{array}{l}\text { Carrying forward lessons learned, via post-project au- } \\
\text { dits. Development of continuous improvement culture. }\end{array}$ \\
\hline TEAM & $\begin{array}{l}\text { Cross-Functional } \\
\text { team working }\end{array}$ & $\begin{array}{l}\text { Involvement of different perspectives: use of team- } \\
\text { building approaches to ensure effective team working } \\
\text { and develop capabilities in flexible problem solving. }\end{array}$ \\
\hline INDIVIDUAL & $\begin{array}{l}\text { Advanced support } \\
\text { tools }\end{array}$ & $\begin{array}{l}\text { Use of tools (CAD, rapid prototyping, computer- } \\
\text { supported co-operative work aids) to assist with quality } \\
\text { and speed of development. }\end{array}$ \\
\hline
\end{tabular}

These key features indicate the necessity for the NPD organisation to undertake substantial groundwork before formation of the NPD team to enable the subsequent success of the NPD process. This groundwork itself may also necessitate pre-NPD training. 
An Evaluation of Organisational Groundwork and Learning Objectives ...

\section{Groundwork 2: Implementing the NPD Strategy}

In a study carried out by Cooper \& Kleinschmidt, [6], ten drivers of time efficiency of the NPD process were considered to be of importance and were found to reduce the overall introduction time of a new product across the varying case studies undertaken (Table 5).

The work of the NPD team consists of things such as doing the homework upfront and determining what the customer really does want and the quality of execution of the new product process, that is after the cross-functional team has been formed and is working both effectively and efficiently. These drivers need to be aligned to the organisation's NPD strategy and groundwork will have to be undertaken to ensure this.

Table 5. Ten Drivers of Time Efficiency of the NPD Process [6].

\begin{tabular}{|l|l|}
\hline \multicolumn{1}{|c|}{ DRIVER } & \multicolumn{1}{c|}{ DESCRIPTION } \\
\hline $\begin{array}{l}\text { Project } \\
\text { organisation }\end{array}$ & $\begin{array}{l}\text { Projects organised as a cross-function, dedicated, accountable project } \\
\text { team, with a strong empowered leader and with senior/top management } \\
\text { support are more time efficient. }\end{array}$ \\
\hline $\begin{array}{l}\text { Early, sharp } \\
\text { product definition }\end{array}$ & $\begin{array}{l}\text { Projects where the project was clearly defined and agreed prior to the } \\
\text { development phase are found to move to market more quickly. }\end{array}$ \\
\hline $\begin{array}{l}\text { Up-front } \\
\text { homework }\end{array}$ & $\begin{array}{l}\text { Projects where solid, thorough and reliable research is done are found to } \\
\text { give fewer problems down the NPD process. }\end{array}$ \\
\hline $\begin{array}{l}\text { Strong market } \\
\text { orientation }\end{array}$ & $\begin{array}{l}\text { Projects that are market-orientated and customer focused, and build the } \\
\text { customer into the process from start to finish, have been found to progress } \\
\text { more quickly. }\end{array}$ \\
\hline A strong launch & $\begin{array}{l}\text { Good advertising and promotion with product availability are key ways in } \\
\text { moving the product to the market quickly. }\end{array}$ \\
\hline $\begin{array}{l}\text { Technical } \\
\text { proficiency }\end{array}$ & $\begin{array}{l}\text { The undertaking of technological / technical activities in a quality fashion } \\
\text { leads to cycle time reduction. }\end{array}$ \\
\hline Synergy & $\begin{array}{l}\text { This is the ability to leverage the companies in house or existing technol- } \\
\text { ogy, production, and marketing skills and resources to advantage, with } \\
\text { regard to improving timeliness. }\end{array}$ \\
\hline $\begin{array}{l}\text { Familiarity } \\
\text { attractiveness }\end{array}$ & $\begin{array}{l}\text { Projects that are more familiar to the company in respect of product type, } \\
\text { markets and technologies also result in improved timeliness. } \\
\text { Products aimed at attractive markets with fast-growing economic climates }\end{array}$ \\
\hline
\end{tabular}


Jonathan Owens

\begin{tabular}{|l|l|l} 
Market & Markets characterised by many competitors, intense aggressive competi-
\end{tabular}

\begin{tabular}{l|ll} 
Competitiveness. & tion and easily switched customers will see more rapid product develop-
\end{tabular} ments.

\section{Groundwork 3: Resource Considerations}

Establishing new product success factors has become an important component in order to ascertain what discriminates between winners and losers in NPD. Deciding this is an important ingredient, as project selection and prioritisation is a critical issue as NPD authorities are required to become more focused and better at allocating scarce development resources [36]. Rapid prototyping, incremental NPD, process modelling, electronic mail (E-mail) and video presentations are a few tools and techniques that can be used to enhance both product and process visibility. Hence, using these simplifies the challenge of maintaining effective communications within the whole work environment. Competitive NPD methodologies and tools become integral to the achievement of the business objectives through the development of new products [26]. The methodology and tools enable the NPD effort to move at a rate that is competitive [7]. For NPDL to be effective then appropriate resources for learning needs to be allocated before the start of the NPD process. Results, to be published, from a recent European funded project, outlined by Bamber and Sharp [2], show that some employers are reluctant to allocate adequate resources for training. Although the employers did sanction training and have some training needs analysis system in place when the pressure of work increased then training was reduced or withdrawn. For NPDL it is crucial that the company and the individuals have a unified vision of NPD, money is allocated for NPDL and sufficient employee time is allocated. Further, the training time should be protected from increasing work pressure.

\section{ASSEMBLING AND DEVELOPING A NPD TEAM}

Assembling the appropriate team and having that team working effectively together is essential [42] for NPD. Depending upon the experience of the individual organisation this may be an easy, or conversely, a complex situation to implement [32]. Procedures need to be introduced which will encourage team participation throughout the NPD process. Likewise, making effective decisions quickly is vital to the success of the NPD process 
whilst keeping commodities in view ensures that information about the NPD effort is constantly under observation [3]. Therefore it is important that everyone contributing to the process knows how to make a swift, accurate decision or knows how to get decisions made. Technique and the adaptation of technique within a particular environment is the base for decision-making success [17]. Subsequently, attempting to create a new product with a pool of talent that is inadequately prepared, or lacks the skills needed to effectively apply the knowledge they possess, in an exercise in futility [12]. Therefore participants should be adaptable, creative, intuitive, knowledgeable, self-motivated and competitive, to name but a few qualities.

\section{ASSESSMENT DURING THE NPD PROCESS AND NPDL}

A significant improvement on the traditional NPD approach is the stagegate approach [9]. This demonstrates a conceptual and operational model for moving a NPD project from idea to launch and is presented here with arrows indicating points of evaluation for NPD feeding back into the start of the process. At this stage new learning objectives may be identified for the individual and team.

Figure 9. Overview of a Typical Stage-Gate NPD Process. Adapted from [9]

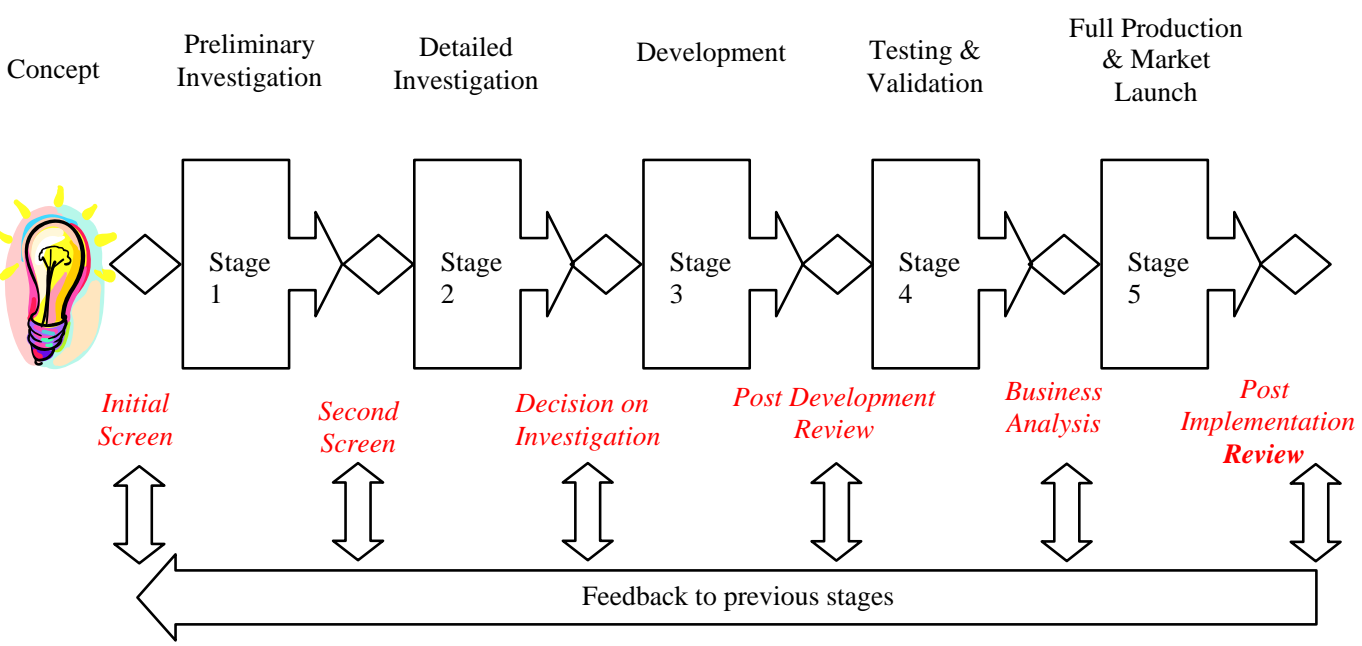

The stage-gate system breaks the NPD project into discrete identifiable stages, five stages being illustrated in figure 9. This number can be 
increased or decreased to suit the NPD team, it can be seen that there are no individual research and development or marketing stages, instead these are incorporate into stages 1, 2 and 3. Each stage is designed to gather the information required to progress the project to the next gate. Each stage consists of a set of parallel activities undertaken by personnel from different functional areas within a company, but working together as a team. In order to manage risk via a stage-gate scheme, the parallel activities within a stage must be designed to gather vital information, so as to drive out technical and business uncertainties [11]. Each stage costs more than the preceding one, so that the fundamental plan is an incremental commitment to the project. Likewise training at later stages of the NPD process could pay great dividends, as a small improvement in performance would lead to large savings. In order to speed products to market, stages can overlap with each other. Long lead-time activities can be brought forward from one stage to an earlier one; projects can proceed into the next stage, even though the previous stage has not been totally completed; and the stages can be collapsed and combined to suit each individual project. All this gives rise to our ninth set of learning objectives, which are concerned with assessment of the NPD process and NPDL.

\section{RISK OF FAILURE}

Despite the importance of NPD, for both present and future prosperity of companies, a high percentage of new products fail when released into the market. Research [25] demonstrates that most of the concepts that enter the NPD process fail to become commercial successes; in fact only fourteen percent (14\%) succeed. As a result, companies developing new products appear more inclined to focus on similar or replica products rather than taking the risk to truly develop truly innovative ones, rather than managing the risk well to enable them to innovate in NPD [12]. Subsequently, radical and innovative products contribute to approximately two percent (2\%) of product marketed [11]. Here we have a requirement to be able to assess risk factors likely to cause new product failure or success. As new product failure rates are so high, and because the costs associated with NPD are usually high, companies have been hesitant to provide the resources to advance the NPD process [11].

As the risks of failure inherent in every new product situation vary, so too do the returns. The balance of investments, risk and returns is a major 
criterion in deciding whether or not to proceed with a new product [23]. As new product forecasting techniques, like the McKinsey Seven S Framework, Balanced Scorecard, can be expensive, both in time and money, careful consideration needs to be assigned before taking them on board [44].

Table 6: Success Rates for Major new Products Over a Five-year Period [19].

\begin{tabular}{|c|c|c|}
\hline $\begin{array}{c}\text { Successful New } \\
\text { Products }\end{array}$ & $\begin{array}{c}\text { Percentage of Companies } \\
\text { Selling primarily to Industrial } \\
\text { Markets }\end{array}$ & $\begin{array}{c}\text { Percentage of Companies } \\
\text { Selling Primarily to Consumer } \\
\text { Markets }\end{array}$ \\
\hline $100 \%$ & 9 & 18 \\
\hline 90 to $99 \%$ & 7 & 4 \\
\hline 80 to $89 \%$ & 16 & 9 \\
\hline 70 to $79 \%$ & 11 & 11 \\
\hline 60 to $69 \%$ & 16 & 12 \\
\hline 50 to $59 \%$ & 15 & 15 \\
\hline 40 to $49 \%$ & 4 & 2 \\
\hline 30 to $39 \%$ & 9 & 4 \\
\hline 1 to $29 \%$ & 5 & 16 \\
\hline $0 \%$ & 8 & $\mathbf{1 0 0}$ \\
\hline Total & $\mathbf{1 0 0}$ & 9 \\
\hline
\end{tabular}

Gruenwald [19] shows how the consequence of success and failure, affects new products over a five-year period (1988-1993), Table 6. It can be seen that half of the companies surveyed had achieved success, with at least two-thirds of the major new products marketed over the last five years. However, the other half reported such success with less than two thirds of their new products. As a result these median values for new 
product success were the same for manufacturers selling to either industrial or consumer markets. The success rate reported by each company represents the percentage of all major new products introduced to the market by the company during the previous five years. Complete success or complete failure is more common among manufacturers catering to consumer markets than amongst those servicing industrial markets [19]. This study covered new products that companies have actually introduced into the market and found that companies situated at either end of the extremes included to an above average extent a number of companies that launched only relatively few major new products.

It can be understood, that a company which sends to market only one or two major new items over a period of time is perhaps either exceptionally cautious or exceptionally short in new product innovation experience. Moreover, the low number of products at risk increases the chances of total success and/or failure. Acknowledging that virtually every new product will inevitably carry some sort of risk does not, however, prevent attempts to reduce such a risk to a minimum. Hence risk analysis is required as a final set of learning objectives. Experience gained from past NPD failures can lead the NPD team into hurrying the process and, as a result, does not allow the team to perform as one [34]. This is understandable as NPD does absorb both financial and human resources from a company, with no real guarantee of clear-cut winners [12].

\section{SUMMARY}

A framework for learning and assessment of that learning has been presented and initial sets of learning objectives have been identified (Table 8), which are required for NPD after the founding groundwork has been undertaken in the emergent NPD organisation (Table 7). The objectives can be used in the analysis of learning needs, which should be undertaken before embarking on NPD and NPDL.

Table 8. NPDL Objectives.

\begin{tabular}{|l|l|}
\hline \multicolumn{1}{|c|}{ Aim } & \multicolumn{1}{c|}{ Work and Skills } \\
\hline Groundwork 1 & Developing the NPD Process \\
\hline Groundwork 2 & Implementing the NPD Strategy \\
\hline Groundwork 3 & Allocating Resources for NPD and NPDL \\
\hline
\end{tabular}


An Evaluation of Organisational Groundwork and Learning Objectives ...

\begin{tabular}{|l|l|}
\hline \multicolumn{1}{|c|}{ Tim } & \multicolumn{1}{c|}{ Work and Skills } \\
\hline \multicolumn{1}{|c|}{ Aim NPD Groundwork } \\
\hline Objectives Set 1 & Organisational Analysis \\
\hline Objectives Set 2 & Barrier Demolition plus Interpersonal Skills \\
\hline Objectives Set 3 & Team Working \\
\hline Objectives Set 4 & Flexible Problem Solving \\
\hline Objectives Set 5 & Using Advanced Support Tools \\
\hline Objectives Set 6 & Facilitating Communication \\
\hline Objectives Set 7 & Maintaining Communication \\
\hline Objectives Set 8 & Decision Making \\
\hline Objectives Set 9 & Assessment of the NPD Process and NPDL \\
\hline Objectives Set 10 & NPD Risk Analysis \\
\hline
\end{tabular}

\section{CONCLUSIONS}

In order to evaluate the effectiveness of any learning, measurements must be taken at a series of levels within the individual, within the team and within the organisation. For NPDL clear specific and general learning objectives need to be set and these have been discussed throughout this paper, however for the learning to be effective preliminary groundwork must be undertaken by the NPD organisation. So there are requirements for both organisational and individual needs analyses. Important characteristics to be investigated by the needs analyses have been present in the model of good practice (Table 4). The analyses will identify the preliminary groundwork that must be undertaken by the organisation and the initial learning objectives for the individuals. It is likely that the organisation is obliged to develop its NPD strategy, NPD process and its NPD resource commitment. Understanding and analysis of the risks associated with NPD is crucial as the cost of failure is high and may increase as the NPD process progresses. Adopting the model of learning along with a stage gate approach can make continual assessment of both the progress of the individuals towards their learning objectives and the progress of the team towards NPD. Solid, thorough and reliable research should be undertaken in order to facilitate fewer problems to occurring later in the NPD process. Subsequently, when conducting the initial analyses the warnings come to the foreground and, if used wisely, through the NPDL framework and 
NPD process presented here will lead to the individual, team and organisation being better armed for NPD.

\section{REFERENCES}

Arthur , H. (1970). A Study of the Training of Professionally Qualified Staff in Industry, $\mathrm{PhD}$ Thesis, University of Salford.

Bamber, D. J. and Sharp, J. (2000). Measuring the Performance of Mature Employees Trying to Learn through Computer based Courseware in SMEs, Towards the Elearning Community Challenges for Business and Education, Bolton International Conference, Centre for entrepreneurship and management, Bolton Institute, pp103110.

Bessant, J. and Caffyn, S. (1997). High Involvement Innovation through Continuous Improvement. International Journal of Technology Management, 14, 1, pp 7-28.

Bloom, B. S. (Editor). (1956). The Taxonomy of Educational Objectives Longman, London.

Bramley, P. (1999). Evaluating effective management learning, Journal of European Industrial Training, City, 23(3): 145-153.

Cooper, RG. and Kleinschmidt, EJ. (1994). Determinants of Timeliness In product Development. Journal of Product Innovation Management, 11, pp381-396.

Cooper, RG. and Kleinschmidt, EJ. (1995). Benchmarking Firms' New Product Performance and Practices. Engineering Management Review, 23, pp112-120.

Cooper, RG. (1988). Predevelopment Activities Determine New Product Success. Journal of Industrial Marketing Management, 17, pp 237-247.

Cooper, RG. (1993). Winning at New Products - Accelerating the Process from Idea to Launch. Perseus Books.

Cooper, RG. (1994). Third Generation New Product Process. Journal of Product Innovation Management, 11, pp 3-14.

Cooper, RG. (1998). Product Leadership: Creating and Launching Superior New Products. Perseus Books.

Cooper, RG. (1999). From Experience: The Invisible Success Factors in Product Innovation. Journal of Product Innovation Management, 16, pp 115-133.

Cooper, RG., Edgett, SJ and Kleinschmidt, EJ. (1998). Portfolio Management for New Products. Addison-Wesley.

Crawford, C. (1991). New Products Management ( $3^{\text {rd }}$ Ed). Irwin, Homewood.

Deming, W. E. (1986), Out of crisis, MIT, Massachusetts.

Dinesh, D. and Palmer, E. (1998). Management by Objectives and the Balance Scorecard: Will Rome Fall Again? Management Decision, 36(6): 363-369.

Edstrom, A; Jonsson, S and Ask, U. (1998). Joint Platforming: Learning from Difference and Differences of Learning. Proceedings from the $5^{\text {th }}$ International Product Development Conference, Brussels, European Institute for Advanced Studies in Management, May, pp349-367. 
An Evaluation of Organisational Groundwork and Learning Objectives ...

Griffin, A. and Page, AL. (1993). An Interim Reports on Measuring product development success and failure”. Journal of Product Innovation Management, September, 10, pp 291-308.

Gruenwald, G. (1995). New Product Development, $2^{\text {nd }}$ Ed. NTC Business Books.

Heywood, J. (1977). Assessment in higher education, London, Wiley.

Johne, A. and Snelson, P. (1988). Successful New Product Development. Blackwell.

Kirkpatrick D. L. (1960). Techniques for Evaluating Training Programs, Journal of the American Society of Training Directors, City, Vol 14, pp 13-32.

Kuczmarski, TD. (1992). Managing New Products - The Power of Innovation. PrenticeHall.

Lawrence, P. and Lorsch, J. (1967). Organisation and Environment. Harvard University Press.

Liberatore, MJ and Stylianou, AC. (1995). Expert Support Systems for New Product Development Decision Making: A modelling framework and applications, pp12961316.

Lilien, GL. and Yoon, E. (1989). Success and Failure in Innovation - A Review of the Literature. IEEE Transactions on Engineering Management.

Lilien, GL. and Yoon, E. (1990). The Timing of Competitive Market Entry: an Exploratory Study of New Industrial Products, Management Science, 36, pp568-585.

Mahajan, V. and Wind, Y. (1992). New Product Models: Practice, Shortcomings and Desired Omprovements. Journal of Product Innovation Management 9, pp129-139.

Maidique, M. and Zieger, B. (1985). The New Product Learning Cycle. Research Policy, 14, pp299-309.

Mann, S. and Robertson, I. T. (1996). What Should Training Evaluate?, Journal of European Training, 20(9): 14-20.

Miller, R. (1998). New Product Development: Look to the customer for ideas. Chemtech '98, November, 28(11): 13-18.

Olthuis, G. (1997). Production Creation at Phillips Electronics. R\&D Management, 27, 3. pp 213-224.

Ostroff, A A. (1991). Training Effectiveness Measures and Scoring Schemes: A Comparison, Personnel Psychology, 44(2): 353-374, 1991.

Rosenthal, SR. and Tatikonda, MV. (1993). Time Management in New Product Development: Case Study findings; Engineering Management Review, 21(3): 13-20.

Rothwell, R. (1992). Successful Industrial Innovation: Critical Success Factors for the 1990’s. R\&D Management 22, pp221-239.

Roussel, P, Saad, KN and Erickson, TJ. (1991). Third Generation R\&D: Managing the link to Corporate Strategy. Harvard Business School Press \& Arthur D Little Inc.

Russell, RS. and Taylor, BW. (1995). Production and Operations Management: Focussing on Quality and Competitiveness. Prentice-Hall.

Smith, P. and Reinertsen, D. (1991). Developing Products in Half the time. Van Nostrand Reinhold, NY.

Thomas, RJ. (1993). New Product Development - Managing and Forecasting for Strategic Success. John Wiley \& Sons.

Twigg, D. (1998). Managing Product Development within a Design Chain. International Journal of Operations \& Production Management, 18, 5, pp 42-51.

Ulrich, GL. and Eppinger, SD. (1995). Product Design and Development. McGraw-Hill. 
Jonathan Owens

Urban, GL., Hauser, JR and Nikhilesh, D. (1987). Essentials of New Product Management. Prentice-Hall.

Wheelwright, S. and Clark, K. (1992). Revolutionising Product Development. Free Press, NY.

Whitworth, B. (1998). The End of Trial and Error. Professional Engineering Magazine, February, IMechE, London, England, pp 32-40. 